\title{
IDENTIFICACIÓN DE UN MANUSCRITO ANDALUSÍ ANÓNIMO DE UNA OBRA CONTRA IBN ḤAZM AL-QURṬUBI \\ (m. 456/1064) ${ }^{1}$
}

\author{
Samir KADDOURI \\ Rabat
}

\section{INTRODUCCIÓN}

La labor efectuada por algunos investigadores ha puesto de manifiesto la proliferación de manuscritos andalusíes en Marruecos. Hace aproximadamente unos 30 años, el director de la Biblioteca de al-Qarawiyyīn de Fez, Muhammad al- 'Ābid al-Fāsī, mostró a Muhammad Ibrāhīm al-Kattānī un fragmento manuscrito mutilado de origen andalusí, donde se ataca encarnizadamente la doctrina zāhirī de Ibn Ḥazm. Después de un estudio exhaustivo, al-Kattānī consiguió identificar la obra y a su autor, pero no llegó a presentar sus conclusiones al respecto $^{2}$. En cualquier caso, a él se debe el hecho de que actualmente exista un microfilm de dicho fragmento en la Biblioteca General de Rabat, que ha sido catalogado bajo el siguiente epígrafe: «Obra contra Ibn Ḥazm, de autor desconocido, cuyo manuscrito original se halla en la Biblioteca de al-Qarawiyyīn» ${ }^{3}$.

En una conversación que mantuve con el profesor Muhammad al-Manūnī en torno a la figura de Ibn Ḥazm, aquél me sugirió la idea de examinar el microfilm ya mencionado, añadiendo que la consulta de este último era preferible a la del manuscrito original, muy deteriorado desde que salió a la luz. Sus palabras me alentaron a descubrir las riquezas que encierra esta obra.

\section{BREVE DESCRIPCIÓN DEL MANUSCRITO}

El manuscrito objeto de este estudio está constituido por 269 folios, de algunos de los cuales sólo se conservan fragmentos y otros sufren los efectos

\footnotetext{
${ }^{1}$ Deseo expresar mi gratitud al profesor P. S. van Koningsveld por haber tenido la amabilidad de revisar la primera versión de este artículo, así como por sus observaciones y correcciones, que han sido tenidas en cuenta en la versión final del texto. Asimismo, aprovecho estas líneas para mostrar mi reconocimiento a la profesora Mercedes García-Arenal, directora de esta revista, por fomentar la investigación que tiene por objeto los estudios andalusíes. La traducción del árabe de este artículo ha sido realizada por Ana María Carballeira, a quien agradezco el excelente trabajo llevado a cabo.

2 Véase M. I. al-Kattānī, «Mu'allafāt Ibn Hazm wa-rasā’ilu-hu bayna anșāri-hi wa-jușūmi-hi», Maŷallat al-taqāfa l-magribiyya, 1 (enero-febrero 1970), 83-107, especialmente 94-95.

${ }^{3}$ Microfilm n. 5 de la Biblioteca General de Rabat.
}

Al-Qantara XXII, 2 (2001) 299-319 
de la acción de la carcoma. Un folio normal suele estar compuesto de 19 líneas escritas cuidadosamente por un andalusí, a quien, como veremos en el siguiente apartado, hay que ubicar cronológicamente en los siglos V-VI/XI-XII ${ }^{4}$. Las palabras aparecen siempre vocalizadas y con puntuación. El copista añade en los dos márgenes de cada página las palabras y las frases que ha olvidado reproducir, aspecto que pone en evidencia que esta versión fue objeto de una buena colación con el original.

El texto consta de introducción, capítulos $(a b w a \bar{a} b)$ y subcapítulos $(f u s ̣ u \bar{l})$. El contenido sólo se ha preservado de forma íntegra en la última página de la introducción, que precede al capítulo preliminar titulado «Respeto y veneración que deben profesar los autores modernos hacia los antiguos» ${ }^{5}$. Asimismo, existen algunas lagunas entre los capítulos y los subcapítulos, en concreto la ausencia de las primeras o últimas líneas de los folios, debido al lamentable estado en el que se encuentra el fragmento, motivo por el cual su organización entraña una gran dificultad. En algunas ocasiones es posible llegar a rellenar las lagunas existentes, especialmente si el texto en cuestión se halla reproducido en obras ya editadas de Ibn Hazm o de otros autores.

La obra se puede incluir en el ámbito de «la polémica interdoctrinal jurídica» ${ }^{6}$ (al-jiläf al-fighì), pero su autor critica también las opiniones de Ibn Hazm $^{7}$ sobre la esfericidad de la Tierra, la filosofía, las ciencias exactas, la educación infantil y la cuestión relativa a la corrupción (taḥrïf) de las Escrituras ${ }^{8}$.

El manuscrito contiene información bio-bibliográfica inédita respecto a Ibn Ḥazm, así como sobre las circunstancias históricas en las que se desenvolvieron sus adversarios, a quienes el autor conocía personalmente. Por otro lado, se debe tener presente que este manuscrito parece ser el único ejemplar que se ha preservado de esta obra.

\footnotetext{
${ }^{4}$ Puede tratarse de la copia en limpio (mubayyada) del propio autor, dado que ésta no contiene faltas de ortografía o de gramática. Asimismo, las citas de Ibn Hazm están cuidadosamente corregidas y todo el texto aparece vocalizado. Además, la caligrafía es muy antigua. Por otro lado, el estado en el que se halla el manuscrito es una prueba evidente de que el transcurso del tiempo ha contribuido a su deterioro (véase la ilustración $n .^{\circ} 1$ ).$$
\text { باب ما يلزم المتأخرين من الاقتداء بالمتقدمين ويجب عليهم من توقيرهم وتعزيرمم } 5
$$

${ }^{6}$ Una gran parte del manuscrito critica la obra Al-Ihkām fi ușūl al-aḥkām de Ibn Hazm.

${ }^{7}$ Estas opiniones figuran en las siguientes obras: Al-Fisal, al-Taqrïb li-ḥadd al-manțiq, Risālat marātib al-'ulūm, Risālat al-tawqīf 'alà šāri' al-naŷāt.

${ }^{8}$ Sobre este último aspecto, véase el apartado 8 de este artículo.
} 


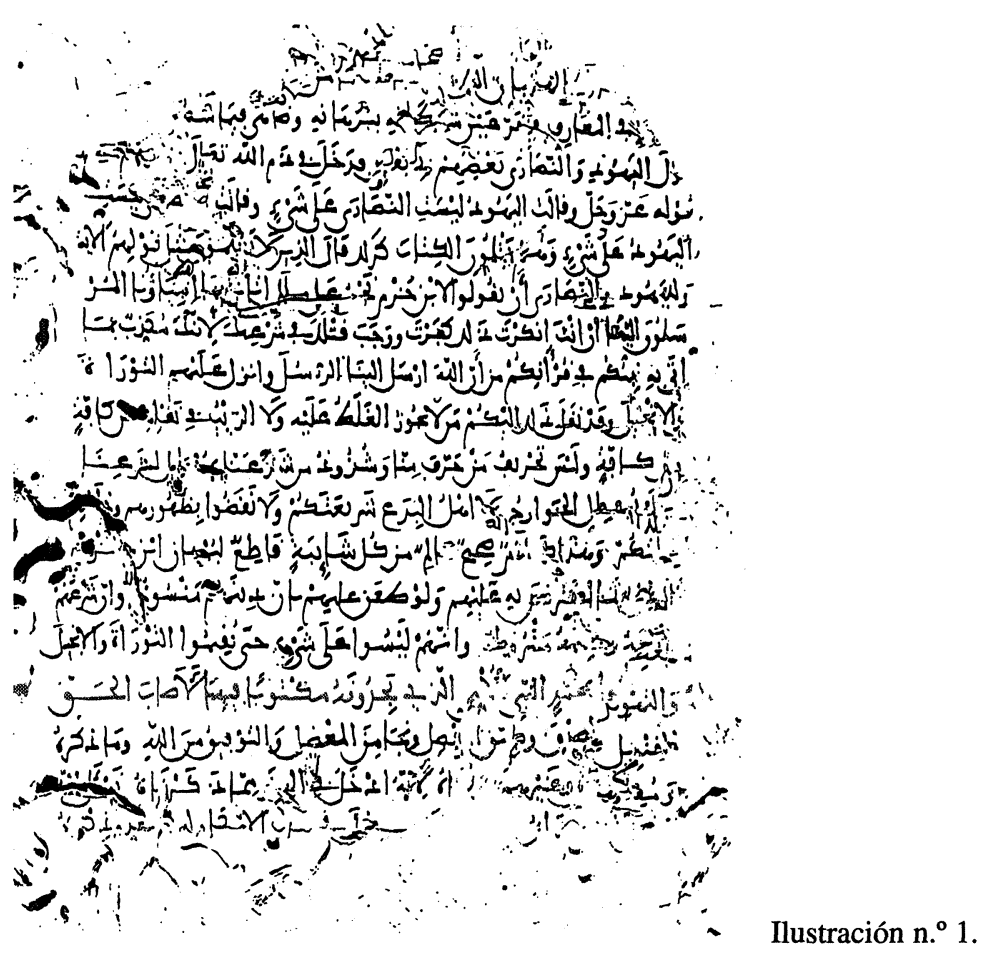

\section{IDENTIFICACIÓN DEL AUTOR Y DEL TÍTULO DE LA OBRA}

La identidad del autor y el título de la obra han sido esclarecidos gracias a los esfuerzos realizados por el profesor al-Kattāni ${ }^{9}$, quien, como ya he advertido anteriormente, no ha publicado información alguna en este sentido. Por esta razón, considero oportuno verificar, en primer lugar, la exactitud de sus hipótesis.

Respecto a la identidad del autor, no cabe duda de que se trata de un destacado sabio mālikí, a juzgar por su habilidad al citar textos de obras pertenecientes al derecho mālikí, como es el caso de la Mudawwana, la Wādiha, el Kitāb de Ibn Lubāba, el Kitāb de Ibn al-Mawwāz, la Risāla de Ibn Abī Zayd alQayrawānī, etc. ${ }^{10}$. Además, es un defensor a ultranza del valor jurídico de los fundamentos del fiqh mālikí.

${ }^{9}$ Véase la referencia mencionada en la nota 2.

${ }^{10}$ Asimismo, cita una obra desconocida de Ibn Abī Zayd al-Qayrawān̄̄, titulada Al-Amr bi-liqtidā' wa-l-nahy 'an al-šudū ' 'an al- 'ulamā'. Véase manuscrito, folio 3v. Como veremos posteriormente, la influencia de este título sobre el del manuscrito es manifiesta. 
Tampoco cabe albergar la menor duda respecto a que el autor es un andalusí del siglo V/XI, es decir, contemporáneo de Ibn Hazm, por diversas razones. Por una parte, el autor nos informa de que llegó a conocer a uno de los hijos de Ibn Ḥazm, cuya kunya era Abū Sulaymān ${ }^{11}$, a quien solicitó confirmación sobre el abandono de la doctrina šāfi ‘í por parte de su padre y su adhesión a la zāhirí, a lo que el hijo respondió afirmativamente ${ }^{12}$. Por otra parte, el autor declara que ha sido discípulo de Abū 'Abd Allāh Muhammad Ibn 'Attāb alQurtubi $^{13}$ (m. 462/1070). Finalmente, el autor narra varias anécdotas relativas a Ibn Hazm, calificándolas de «escandalosas», y confiesa haber recibido este tipo de información de alguien que conocía de cerca a Ibn Hazm, lo cual demuestra que se relacionaba con algunos de los enemigos de éste ${ }^{14}$.

Por otro lado, he reparado en el hecho de que, al comienzo de varios párrafos, el copista empieza por la letra 'ayn ${ }^{15}$, pudiendo tratarse de la inicial del nombre propio del autor. En tan sólo dos ocasiones se encuentra la expresión árabe qāla 'İsà $b$. Sahl ${ }^{16}$. Por tanto, cabe considerar la posibilidad de que la 'ayn pertenezca al nombre de 'Īsà b. Sahl y que éste sea el autor de la obra, especialmente si tenemos en cuenta los siguientes aspectos. En primer lugar, entre los discípulos de Muhammad b. 'Attāb al-Qurțubī figura el nombre de 'Īsà b. Sahl al-Asadī alŶayyānī, miembro de la šūrà de Córdoba y Toledo, posteriormente nombrado cadí de Ceuta, Tánger y finalmente de Granada, donde falleció en 486/1093 ${ }^{17}$. En

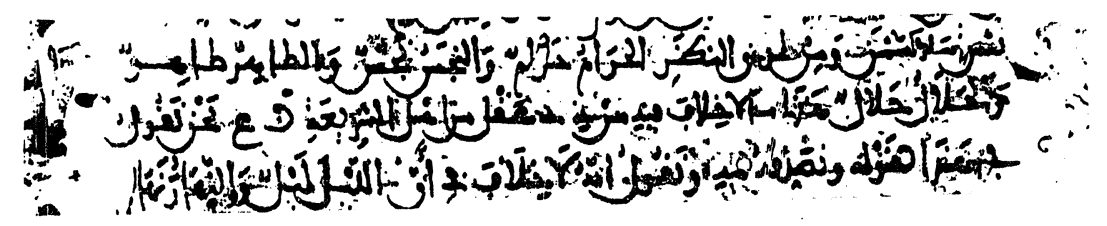

Ilustración n. ${ }^{\circ}$ 2. Foto de una página del Ms. con la letra 'ayn que se refiere a 'Īsà b. Sahl (fin segunda línea).

\footnotetext{
${ }^{11}$ Se trata de Abū Sulaymān al-Muṣ'ab b. 'Alī b. Ahmad b. Sa'īd b. Ḥazm. Originario de Córdoba, donde estudió con Abū Marwān al-Ṭubnī en el mes de rabī' II del año 457/1065. Véase Ibn al-Abbār, al-Takmila li-Kitāb al-Ṣila, ed. 'A. S. al-Harrās, Casablanca, 1990, II, 187-188.

${ }^{12}$ El texto árabe reza:

وقد قررت ابنه أبا سليمان على هذا فأقر أنه (ابن حزم) كان شافعيا ثم صار ظاهريا

${ }^{13}$ Sobre la biografía de este personaje, véase cadí 'Iyāḍ, Tartīb al-madārik, ed. S. A 'rāb, Rabat, 1983, VIII, 131-134, e Ibn Baškuwāl, Kitāb al-Sila, ed. 'I. al-'Aț̣ār, El Cairo, 1955, II, pp. 514-517.

${ }^{14}$ Para más información al respecto, véase el apartado 7 de este artículo.

${ }^{15}$ Véase la ilustración $n .^{\circ} 2$ anexa a este artículo.

${ }^{16}$ Véanse las ilustraciones anexas a este artículo (n. ${ }^{\text {os }} 3$ y 4 ).

${ }^{17}$ Véase la biografía de Ibn Sahl en 'Iyāọ, Tartỉb al-madārik, VIII, 182-183 e Ibn Farhūn, alDībāŷal-mudhab, ed. M. al-A. Abū l-Nūr, El Cairo, 1972, II, 70-72.
} 


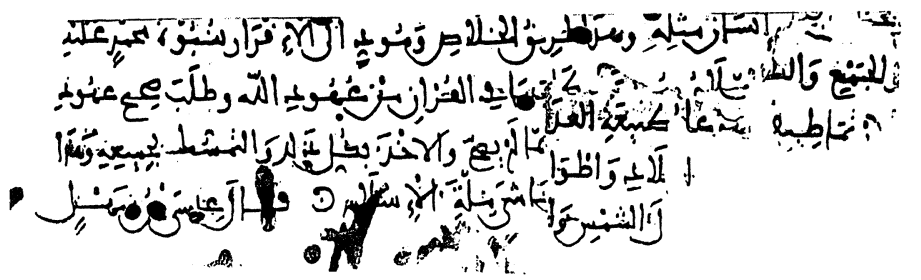

Ilustración n. ${ }^{\circ}$ 3. Foto de una página del Ms. con la expresión «qāla 'İsà b. Sahl» (fin de la última línea).

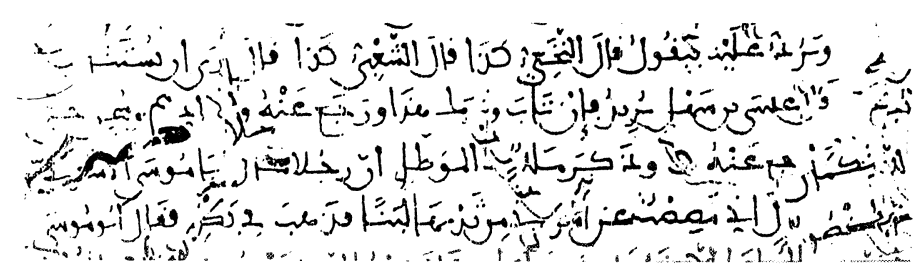

Ilustración n. ${ }^{\circ}$ 4. Foto de una página del Ms. con la expresión «qāla 'ísà $b$. Sahl» (comienzo segunda línea).

segundo lugar, el autor afirma que se trasladó a Ceuta, donde también practicó la docencia, durante el período comprendido entre los años 461-470/1068-1077 ${ }^{18}$. En tercer lugar, en su obra Al-I 'lām bi-nawāzil al-aḥkām, 'Īsà b. Sahl introduce sus palabras con la misma expresión qāla l-qạ̣̄i 'î̀à $b$. Sahl ${ }^{19}$. Es muy posible que el término al-qā dị se deba a una adición debida a los alumnos del autor o a los copistas posteriores. Por último, el estilo en el que están redactadas las Nawāzil de Ibn Sahl y el estilo que presenta el fragmento manuscrito es el mismo.

En lo que se refiere al título de la obra, al-Kattānī consideraba que Ibn Sahl era el autor material de un libro titulado Al-Tanbih 'alà šudū Ibn Hazm, del cual el fragmento objeto de este estudio era el único vestigio ${ }^{20}$. En mi opinión, al-Kattānī ha podido deducir el título de la obra a partir del tema que en ésta se aborda. No obstante, en su lugar, yo habría expuesto otra argumentación.

Es frecuente que el autor acuse a su adversario zāhirí de $\breve{s} u \underline{d} \bar{u} \underline{d}$, es decir, de apartarse de la doctrina dominante. Así, por ejemplo, dice: «Nuestro propósito en este libro es advertir sobre el extremismo de Ibn Hazm» ${ }^{21}$. En otro lugar

${ }^{18}$ Véase el segundo capítulo del manuscrito, titulado Bāb fi dikr tabdì‘ Ibn Hazm li-l-ṣậāba wa-l-tābi 'in wa-stijfäfi-hi bi-ŷamì ' a'immat al-muslimin, folio 5 r.

${ }^{19}$ Véase el manuscrito n. ${ }^{\circ}$ D3398 de la Biblioteca General de Rabat, 271.

${ }^{20}$ Véase la referencia citada en la nota 2.

لم نقصد في كتابنا هذا إلا إلى التنبيه على شذوذ ابن حزم 21 
declara: «Voy a citar una parte, señalando su ignorancia [...] y su extremismo, en el que no incurrieron los autores anteriores ni posteriores a él» ${ }^{22}$. Asimismo, he tenido la ocasión de leer la Tesis Doctoral de Tawfíq al-Galbazūiñ en relación con la doctrina zāhirí en Marruecos y al-Andalus ${ }^{23}$, en la que cita un pasaje del repertorio titulado Barnāmầ šuyüj al-Ru'ayn $\bar{\imath}^{24}$, donde se puede leer «esta versión se halla también en la obra del cadí Abū l-Aṣbag b. Sahl, titulada $A l$-Tanbih 'alà šudū $I$ Ibn Hazm» ${ }^{25}$. He podido localizar y verificar la existencia de este texto en el repertorio citado por al-Galbazūrī. Teniendo en cuenta estas consideraciones, se puede afirmar que 'İsà b. Sahl es el autor del Tanbih .

\section{FIJACIÓN DE LA FECHA DE REDACCIÓN}

Existen varias razones que me llevan a considerar que 'Îsà b. Sahl compuso su Tanbih después de la muerte de Ibn Hazm.

En la introducción del manuscrito puede leerse: «Él (Ibn Ḥazm) abandonó Mallorca, dirigiéndose a Denia, posteriormente a Sevilla y finalmente a su qarya en la región de Niebla, donde falleció en el año 456/1064 durante los días [del reinado] de al-Mu 'tadid». Este texto indica que Ibn Sahl escribió después de la muerte del rey de Sevilla al-Mu 'tadid, es decir, después de $461 / 1069^{26}$. Esta hipótesis aparece reforzada por otros textos del manuscrito, donde Ibn Sahl dice: «Nuestro maestro Ibn 'Attāb —Dios tenga misericordia de él— [...]», desprendiéndose que Ibn Sahl escribió después de 462/1070, año en el que falleció Ibn 'Attāb. Asimismo, en otra ocasión Ibn Sahl aporta nuevos datos para fijar con más precisión la fecha de redacción, al declarar: «Estaba yo con nuestro maestro Ibn 'Attāb -Dios tenga misericordia de él-, cuando recibió una carta del alfaquí de Almería Abū 'Umar b. Rašĩq a propósito de Ibn Ḥazm, hace más de 30 años» ${ }^{27}$. folio $1 \mathrm{v}$

22 وأذكر طرفا من جهله [...] وشذوذه بما لم يقله أحد من تقدم أو تأخر , Véase la introducción del manuscrito, $23 \mathrm{v}$.

${ }^{23}$ T. al-Galbazūīi, Al-Madrasa al-zāhiriyya bi-l-Magrib wa-l-Andalus naš'atu-hā a'lāmu-hā wa-ataru-hā, Tesis Doctoral, Tetuán, 1999-2000, II, 689-691. El autor no ha consultado el manuscrito ni su microfilm, tan sólo el artículo de al-Kattānī y el repertorio de al-Ru'aynī.

${ }^{24}$ Ed. I. Šabbūḥ, Damasco, 1962, 33-34. Se trata de Abū l-Ḥasan 'Alī b. Muḥammad b. 'Alī lIšbilī al-Ru'aynī (m. 666/1261).

وقد ذكر عنه نحو هذا القاضي أبو الأصبغ ابن سهل في كتابه الذي سماه التنبيه على شذوذ ابن حزم

${ }^{26}$ Véase Ibn 'Idārī l-Marrākušī, Al-Bayān al-mugrib, ed. E. Lévi-Provençal, París, 1930, III, 204 y 283-284 y 'Ābd al-Wāhid al-Marrākušī, $A l-M u$ 'ŷib fi taljịs ajbār al-Magrib, eds. M. S. al'Aryān y M. 'A. al-'Alamī, Casablanca, 1978, 149.

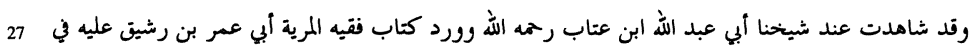

$$
\text { أمر ابن حزم هذا منذ أزيد من ثلائين سنة. }
$$


Desde este punto de vista, el problema está prácticamente resuelto, ya que la fijación de la fecha de llegada de esta carta permite determinar con bastante exactitud la fecha de redacción de la obra. Asimismo, es preciso tener presente que Abū 'Umar Ahmad b. Rašīq falleció en 446/1054 ${ }^{28}$, es decir, que la fecha de envío de la misiva a Ibn 'Attāb no puede ser posterior a este año. Por otro lado, al-Humaydī, discípulo de Ibn Hazm, atestigua haber visto en varias ocasiones al secretario Ahmad b. Muhammad b. Burd visitando a su maestro en Almería con posterioridad al año 440/1048 ${ }^{29}$. Ahora bien, según Ibn al-Abbār, Ibn Burd había fallecido en 445/1053 en Almería ${ }^{30}$. Por tanto, Ibn Hazm debió de llegar a esta ciudad entre los años 441-445/1049-1053, y es muy probable que su estancia allí hubiese suscitado el temor del alfaquí Ibn Rašĩ quien acabó por solicitar la ayuda de Ibn 'Attāb. Esta hipótesis está basada en el testimonio de Ibn Ḥazm, quien se refiere a sus adversarios mālikíes expresándose en los siguientes términos: «posteriormente ellos han buscado la protección de sus pares, dirigiendo cartas necias a Ibn (Abī) Riŷāl de Denia y a 'Abd al-Haqq de Sicilia» ${ }^{31}$. Tomando en consideración los datos precedentes, se puede fijar aproximadamente la fecha de envío de la carta de Ibn Rašì entre los años 441-446/1049-1054. Pero si a éstos se añaden treinta años más, se podría ubicar la fecha de redacción entre 471-476/1078-1083.

No obstante, en mi opinión, se puede considerar el año 480/1087 como la fecha límite de redacción por una serie de razones. Por una parte, Ibn Sahl dice: «hace más de treinta años». Por otro lado, éste compuso su obra Al-I lām bi-

${ }^{28}$ Véase la biografía de este personaje en Ibn Baškuwāl, Al-Sila, I, 57 e 'Iyād, Tartib al-madārik, VIII, 154-155. Según 'Iyāạ, أبو عمر أحمد بن رشيق المربي شيخ فقهاء المرية وكبير مفتيها.

${ }^{29}$ Véase al-Humaydī, Ŷidwat al-muqtabis fi ta'rij 'ulamā' al-Andalus, ed. I. al-Abyārī, Beirut, 1983, I, 183-184. Esta información tan útil de al-Humaydī ha pasado desapercibida para los historiadores modernos. Se puede observar que el año 440/1048 constituye una referencia que permite localizar los acontecimientos de los que se ignora la fecha exacta en que acaecieron. Asimismo, alHumaydĩ dice: قبل الأربعين وأربعمائة (I, 187). Este año puede corresponder a la fecha de la expulsión de Ibn Ḥazm de Mallorca después de su fracaso ante Abū l-Walīd al-Bāŷī; al-Ḥumaydĩ acompañó a su maestro en el exilio.

${ }^{30}$ Este personaje aparece citado en la biografía de su padre Muhammad b. Ahmad b. Burd («cordobés que residió en Almería, padre de Abū Ḥafș b. Burd al-Aṣgar, quien falleció en vida de su progenitor en Almería en el año 445/1053»). Véase Ibn al-Abbār, Al-Takmila, I, 314.

$$
\text { ; فعادوا إلى المطالبة عند أمثالمم فكتبوا الكتب السخيفة إلى مثل ابن أبي ريال بدانية وعبد المتق بصقلية } 31 \text {; }
$$

véase Rasā'il Ibn Hazm, ed. I. Abbās, Beirut, 1987, III, 116. El nombre de Ibn Abī Riyāl ha sido escrito «Ibn Ziyād» en el texto impreso, ahora bien, Ibn Abĩ Riyāl fue cadí de Denia durante el reinado de Muŷāhid al-'Āmirī. Este juez falleció en torno al año 440/1048. Su nombre completo era Abū 'Umar Aḥmad b. al-Ḥasan b. 'Uțmān al-Gassānī; véase Ibn al-Abbār, Al-Takmila, I, 24-25. Asimismo, se puede 
nawāzil al-ahkām durante el bienio 472-473/1079-1080 ${ }^{32}$. En ella aborda (por fin) la cuestión de las herejías que surgieron en el seno del Islam, pero sin mencionar la doctrina zāhirí entre ellas, al contrario de lo que sucede en su Tanbih

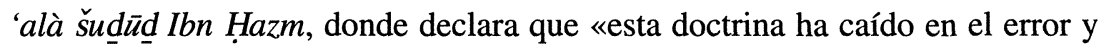
ha fundamentado sus principios en los de los š̄i ‘íes, imāmíes y los jāriŷíes»" ${ }^{33}$. De este hecho parece desprenderse que Ibn Sahl redactó el Tanbīh después de sus Nawāzil.

Finalmente, es preciso recordar que Ibn Sahl tuvo una vida muy inestable después del año 480/1087. En 481/1088 acompañó al emir almorávide Yūsuf b. Tāšufin a la región de Murcia con el ejército, que había sitiado la fortaleza cristiana denominada hiṣn Lịt (Aledo) ${ }^{34}$. Después de esta conquista, el emir de Granada 'Abd Allāh b. Buluggīn dirigió un escrito a Ibn Sahl, designándolo

observar que, entre las cartas desaparecidas de Ibn Hazm, figura el siguiente título Al-Risāla al-balqā' $f i$ l-radd 'alà 'Abd al-Haqq al-Siqillì; véase al-Dahabì, Siyar a 'läm al-nubalā', Beirut, 1986, XVIII, 195.

32 Por una parte, en la introducción de la obra de Nawäzil de Ibn Sahl se puede leer:

; وقد كان ابتداء [له] يوم السبت لعشر خلون من المرم سنة اثنين وسبعين وأربعمائة

véase el manuscrito n. 838 qāf de la Biblioteca General de Rabat, p. 2. Por otra parte, en el colofón del manuscrito n..$^{\circ}$ 1728D (folio 105v) de la Biblioteca General de Rabat relativo a las Nawāzil de Ibn Sahl aparece el siguiente texto:

$$
\text { والحمد الله كثيرا الكتاب في نسخة مؤلفه وكان فراغه منه يوم الأحد لتسع بقين من المحرم سنة ثلاث وسبعين وأربعمائة }
$$

(en el texto árabe en lugar de sab'ina aparece tis 'ina, errata debida seguramente al copista, ya que Ibn Sahl falleció en el año 486/1093)

${ }^{33}$ Ibn Sahl se basa en un texto de 'Abd al-Wahhāb al-Bagdādī para afirmar:

$$
\begin{aligned}
& \text { وقال بعض البغدادين عنهم: هم أتباع الخوارج. قال: وإنما أخذ داود بن علي مذهبه على علماء الإمامية } \\
& \text { وهم كفار [...] هذا كلام البغدادي وإن قوله إن الظاهرية أخذوا مذهبهم عن الإمامية لا تصدت لأن ابن حزم صرح } \\
& \text { في تواليفه أنه لا يبوز الأنح بقول أحد لا صحابي ولا غيره [...] كما تقول الإمامية أنه لا يبوز لأحد أن يقول برأيه } \\
& \text { في الحواديث إلا الإمام. }
\end{aligned}
$$

Véase la sección del manuscrito del Tanbīh que trata de la crítica del Ihkām de Ibn Hazm.

34 Véase el manuscrito privado que se halla en Marruecos (fechado el 15 de rabī' II del año 978/1570) de las Nawāzil de Ibn al-Hāŷŷy al-Qurțubī, 17. Reproduzco a continuación el texto árabe:

$$
\begin{aligned}
& \text { أحبرني الفقيه أبو الوليد الشيتلي صاحبنا أكرمه الله قال: سألت الفقيه أبا الأصبغ ابن سهل ونخن محاصرون } \\
& \text { لحصن لييط مع أمير المؤمنين يوسف بن تاشفين [...] فدخلت على عيسى بن سهل قبل فرحب بي وقام إلي. }
\end{aligned}
$$

Respecto a la conquista, véase Ibn 'Idārī Al-Bayān al-mugrib, IV, ed. I. 'Abbās, Beirut, 1967, 141-143. 
cadí de esta ciudad ${ }^{35}$ en respuesta a la proposición realizada por el alfaquí Ibn al-Qulay 'ī. Entre 481/1088 y 483/1090 Ibn Sahl es enviado (unas dos veces) a Marruecos en calidad de embajador de Ibn Buluggīn a la corte de Yūsuf b. Tāšufinn ${ }^{36}$. En 483-484/1090-1091 los almorávides ordenan la deportación de 'Abd Allāh b. Buluggīn a Marruecos. Poco tiempo después, Ibn Sahl es destituido de su cargo de cadí ${ }^{37}$. Falleció en Granada en el año 486/1093.

\section{DETERMINACIÓN DEL LUGAR DE REDACCIÓN DE LA OBRA}

Respecto al lugar donde Ibn Sahl redactó la obra en la que ataca a Ibn Hazm, es preciso tomar en consideración que el primero era aún mušāwar en Córdoba el 3 de raŷab del año 464/1072 ${ }^{38}$. Sus biógrafos nos informan de que posteriormente Ibn Sahl se trasladó a Ceuta, donde su gobernador bargawātī le dispensó una buena acogida. Allí se dedicó a la docencia y desempeñó el cargo de cadí. Ibn Sahl se refiere en el Tanbīh a su llegada a Ceuta como un suceso que tuvo lugar entre los años 461-470/1068-1077 ${ }^{39}$. Su forma de narrarlo me induce a pensar que ya no se encontraba en esta ciudad cuando escribió el Tanbīh. Según la biografía de Ibn Sahl, éste ejerció el cargo de cadí de Tánger después de residir en Ceuta. Ahora bien, de su obra AlI'lām bi-nawāzil al-aḥkām se desprende que Ibn Sahl era ya mušāwar en Tánger, al menos después del año $476 / 1083^{40}$. Además, Ibn al-Abbār, por su parte, nos informa de que el alfaquí Aḥmad b. Mụ̣ammad b. Hamdīn se había encontrado con el cadí Ibn Sahl durante su visita a Tánger en el año 479/1086 ${ }^{41}$. Por tanto, este último debió de componer el Tanbīh en Marruecos, probablemente en Tánger, en el período comprendido entre los años 476-480/1083-1087.

\footnotetext{
${ }^{35}$ Véase 'Abd Allāh b. Buluggīn, Kitāb al-tibyān, ed. A. T. al-Tỉīi, Rabat, 1995, 132-134.

36 Véase ibidem, 153-154 y Abū l-Hasan al-Nubāhī, Al-Marqaba al-'ulyā, ed. E. LéviProvençal, El Cairo, 1948, 97.

${ }^{37}$ Véase Ibn 'Id̄ārī, Al-Bayān al-mugrib, IV, 143-144; al-Nubāhī, Al-Marqaba al-'ulyā, 97, e Ibn Buluggīn, Kitā ă al-tibyān, 155-164.

${ }^{38}$ Véase el manuscrito n. ${ }^{\circ} 3398 \mathrm{D}$ de la obra Al-I'lām bi-nawāzil al-aḥām de Ibn Sahl, que se halla en la Biblioteca General de Rabat, 247.

${ }^{39}$ Más adelante ofreceré el texto árabe completo (v. nota 53).

40 Véase la addenda de Ibn Sahl varios años después de la redacción final de sus Nawāzil en el manuscrito n. ${ }^{\circ} 3398 \mathrm{D}$ de la Biblioteca General de Rabat, 271.

${ }^{41}$ Véase Ibn al-Abbār, Al-Takmila, I, 29.
} 


\section{El VALOR HISTÓRICO DEL MANUSCRITO}

El manuscrito contiene un número bastante considerable de datos y noticias relativos a la vida, la doctrina, los adversarios y los protectores de Ibn Hazm. En este apartado voy a presentar la información más relevante a este respecto.

\subsection{Sobre las obras perdidas de Ibn Hazm}

Dado que en la obra objeto de este trabajo Ibn Sahl se esfuerza en refutar la doctrina de Ibn Ḥazm, al haber caído un libro de éste en manos de aquél, este último copia párrafos enteros para criticarlos posteriormente. Gracias a este sistema se han preservado largos pasajes extraídos de obras actualmente perdidas de Ibn Hazm.

Asimismo, por una parte, Ibn Sahl alude a los motivos que han llevado a Ibn Hazm a redactar sus obras y, por otra, ofrece sus títulos completos y, en algunos casos, las fechas en que Ibn Hazm las ha transmitido a sus discípulos.

A continuación ofrezco una breve reseña de las obras perdidas de Ibn Hazm a partir de la información contenida en el manuscrito:

a) Kitāb al-i'rāb 'an kašf al-iltibās al-wāqi' bayna aṣhāa al-ẓāhir wa aṣhāa b al-qiyās

A propósito de esta obra, Ibn Sahl indica que «las cuestiones (mas $\left.\bar{a}^{\prime} i l\right)$ de este capítulo se elevan a doce y muestran de forma manifiesta el extremismo (šudūd $)$ de Ibn Hazm. [...] A causa de estas cuestiones ha sido objeto de críticas, e incluso ha sido acusado de infidelidad (al-kufr) en algunas ocasiones. Al tener conocimiento de ello, compuso una obra titulada Kitāb al-i ' $r a ̄ b ~[. .$.$] , don-$ de hace referencia a estas cuestiones, con la finalidad de demostrar lo acertado de sus principios» ${ }^{42}$. Posteriormente, Ibn Sahl trae a colación las palabras de

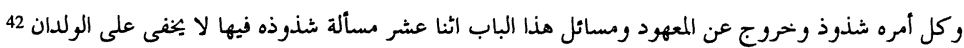

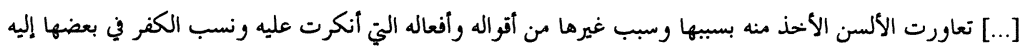

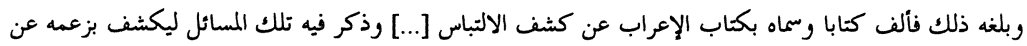

$$
\begin{aligned}
& \text { وجه الحت فيها. } \\
& \text { فصل في ذكر ما شذ فيه عن جميع الأمة وخالف فيه جميع الأثة. }
\end{aligned}
$$


Ibn Ḥazm en relación con cada cuestión, criticando uno por uno los argumentos de su adversario zaăhirí. Desgraciadamente, estas partes del manuscrito se hallan muy deterioradas.

Al-Dahabī clasificó este libro entre las obras menores y los fascículos compuestos por Ibn Hazm $^{43}$. Es preciso recordar que Ibn Hazm había compuesto una gran obra titulada Al-I'rāb 'an al-ḥayra wa-l-iltibās al-mawŷūdayn fĩ mad̄āhib ahl al-ra'y wa-l-qiyās ${ }^{44}$. Es éste un libro polémico en contra de los hanafíes y los mālikíes. Por tanto, se trata, sin lugar a dudas, de dos obras distintas, a pesar de la similitud de sus títulos, puesto que la primera es un fascículo, según al-Dahabī, mientras que la segunda es una obra voluminosa, pues el fragmento de su primer volumen, preservado en la biblioteca Chester Beatty (Dublín n..$^{\circ}$ 3482), está compuesto por 214 folios ${ }^{45}$. Asimismo, hay que tener presente que Ibn Hazm se había referido a uno de sus escritos como «nuestra obra sobre estas cuestiones» (kitābu-nā fi lmasā' $i l)^{46}$. En el caso de que se tratara de la misma obra mencionada por Ibn Sahl, se podría considerar que su fecha de composición es anterior a la del Kitāb al-ị̣kām fi uṣūl al-ạ̣kām, donde aparece citada. Ahora bien, el Iṇkām fue compuesto a lo largo de varios años, desde $430 / 1038{ }^{47}$ hasta después de 437/1046 ${ }^{48}$. El mismo Ibn Ḥazm nos informa de que tenía la costumbre de componer varias obras al mismo tiempo ${ }^{49}$. Este aspecto me induce a pensar que el libro citado por Ibn Sahl fue redactado probablemente en Mallorca, donde se encontraba Ibn Hazm entre los años 430-440/1038-1048, disfrutan-

${ }^{43}$ Véase al-Dahabī, Siyar a 'lām al-nubalā', XVIII, 195. Véase también Ibn Bassām, Al-Dajīra fi mahāsin ahl al-Ŷazira, ed. I. 'Abbās, Beirut, 1979, II, 171.

${ }^{44}$ Véase Ibn Ḥazm, Al-Iḥkām fi uṣūl al-ạ̣kām, ed. A. Šākir, Beirut, 1980, IV, 222, y VIII, 125 .

${ }^{45}$ En la Biblioteca General de Rabat existen dos microfilms (n. ${ }^{\circ} 1019$ y n.. $\left.{ }^{\circ} 1016\right)$ de dos fragmentos del primer volumen de esta obra. Ambos manuscritos fueron escritos por Badr al-Dīn Abū Ahmad Muhammad b. Ibrāhīm al-Dimašqī, conocido por al-Badr al-Baštakī (m. 830/1426). Este sabio y célebre copista, residente en Egipto, abandonó la doctrina šāfi'í y adoptó la zāhirí debido a las lecturas que había realizado de las obras de Ibn Ḥazm. Véase su biografía en Ibn Hayar, Al-Dayl 'alà l-durar al-kāmina, Beirut, 1998, 239-240.

${ }^{46}$ Véase Ibn Hazm, Al-Ihkām, III, 158.

${ }^{47}$ En el tercer capítulo del Iḥkām, Ibn Ḥazm declara que «el último imām de los šìíes e imāmíes falleció hace 170 años» y en el Fisal fija la fecha de muerte en 260/873. Por tanto, Ibn Hazm debió de escribir este capítulo en 430. Véase Al-Iḥkām, I, 17, y Al-Fisal, Beirut, 1985, IV, 158.

${ }^{48} \mathrm{Ibn}$ Ḥazm alude a la muerte de Makkī b. Abī Ṭālib, sabio cordobés que falleció en 437/1046. Véase Al-Ihkām, IV, 167.

${ }^{49}$ En la Risāla fi faḍl ahl al-Andalus de Ibn Ḥazm (II, 186) se puede leer:

ولنا فيما تحققنا به تآليف جمة منها ما قد تقدم ومنها ما قد شارف التمام ومنها ما قد مضى منه صدر ويعين

$$
\text { الله على باقيه }
$$


do de una existencia más pacífica bajo la protección de su gran amigo Abū l'Abbās b. Rašìq, gobernador de esta isla.

\section{b) Kitāb al-qawā'id}

En lo que se refiere a esta obra, Ibn Sahl comenta que «cuando él (Ibn Ḥazm) compuso el Kitäb al-qawā'id según su doctrina [...], yo vi uno de sus volúmenes en casa de un amigo mío de Córdoba y lo hojeé» ${ }^{50}$. Estas palabras demuestran que se trataba de una obra muy amplia, ya que estaba constituida por varios volúmenes (asfār). Esta hipótesis es confirmada por otro testimonio ofrecido por al-Dahabī con respecto a dos obras voluminosas de Ibn Ḥazm, cada una de ellas compuesta por mil folios. Según sus palabras, «él (Ibn Ḥazm) ha (compuesto) el Kitāb al-imlā' fi qawā 'id al-fiqh de mil hojas [...], así como el Kitāb durr al-qawā ${ }^{\prime} i d$, siguiendo los principios de la doctrina zaăhirì» ${ }^{51}$. En mi opinión, en una parte de esta obra Ibn Ḥazm ha reunido las condiciones que debe respetar ahl al-dimma ${ }^{52}$.

\section{c) Kitāb al-nukat al-mū $\hat{y} a z a$}

Según palabras de Ibn Sahl, «Ibn Ḥazm compuso una obra breve, de aproximadamente diez folios, titulada Kitāb al-nukat al-mū ŷaza fi nafy al-umūr almuḥdata fi usūl al-din min al-ra' y wa-l-qiyās wa-l-istiḥsān wa-l-ta 'lìl wa-l-taqlid. [...] Yo he visto un ejemplar de este libro en Córdoba y he copiado las citas que voy a exponer aquí. Posteriormente, me trasladé a Ceuta durante los años 461-470/1068-1077, donde uno de mis alumnos me proporcionó otra copia (de la misma obra), que fue leída en presencia de Ibn Hazm en 437/1046. Entonces yo mostré a este estudiante los errores que Ibn Hazm había cometido en ella.

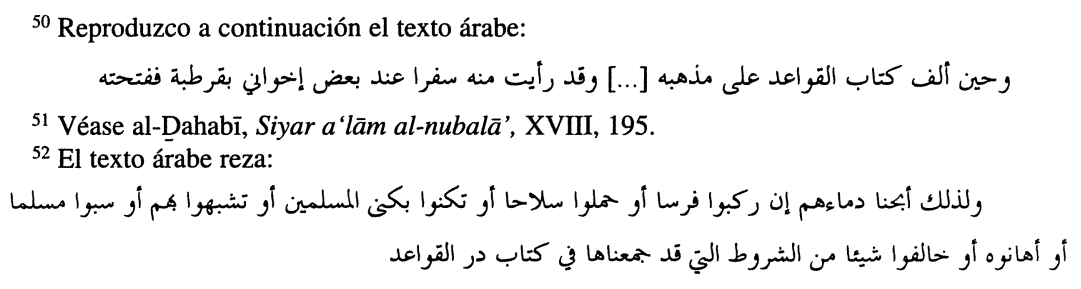

Véase Al-Iḥkām, III, 157. 
Una vez convencido, el estudiante rompió y despedazó su copia del libro en presencia de testigos» ${ }^{53}$.

Entre otras cosas, este texto nos informa de que el Kitāb al-nukat es una obra muy breve, de aproximadamente 10 folios manuscritos ${ }^{54}$. Seguramente fue compuesta antes o en el transcurso del año 437/1046, quizás en Mallorca, al igual que el ya mencionado Kitäb kašf al-iltibās. Además, en el siglo v/XI los libros de Ibn Hazm fueron difundidos por sus discípulos en Marruecos. Por último, la confrontación de las citas tomadas de esta obra por Ibn Sahl con el texto de la obra titulada Mulajjaș Ibtāal al-qiyās ${ }^{55}$ ha puesto de relieve una gran similitud entre el Kitāb al-nukat y el Mulajjaṣ. No obstante, he podido comprobar que este último es, en realidad, un mero resumen efectuado por alDahabi ${ }^{56}$. Desde este punto de vista, no se puede considerar que el Kitāb alnukat al-mūyaza se haya perdido totalmente.

\section{d) Kitāb al-murațāz}

Ibn Sahl atribuyó esta obra a Ibn Ḥazm sin añadir información alguna al respecto. Según parece, aquél había oído hablar de ella, sin que se le hubiera presentado jamás la oportunidad de verla. Se trata de un libro de «gracias y donaires» ([...] kitābi-hi fi l-muḍhikāt wa-l-jurafāt). Me pregunto si podría tratarse del Collar de la Paloma (Ṭawq al-ḥamāma), si bien ésta es una mera conjetura.

${ }^{53}$ Éste es el texto árabe:

$$
\begin{aligned}
& \text { ألف ابن حزم كتابا صغيرا نحو عشر ورقات ترجمه بكتاب النكت الموجزة في نفي الأمور المحدثة في أصول }
\end{aligned}
$$

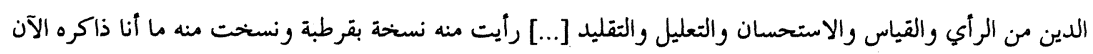

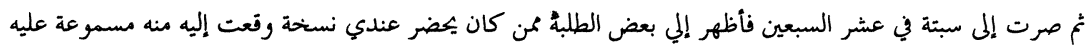

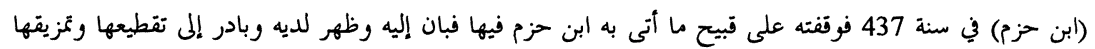

$$
\begin{aligned}
& \text { بحضرة الشاهدين } \\
& \text { باب ذكر تبديع ابن حزم للصحابة والتابعين واستخفافه بجميع أثمة المسلمين }
\end{aligned}
$$

${ }^{54}$ Esta estimación de parte de Ibn Sahl no es correcta. Como demostraremos en otro artículo, el número de folios es superior a 10.

${ }^{55}$ Editada por Sa'īd al-Afgānī (Damasco, 1960), tomando como base un manuscrito del propio al-Dahabī.

${ }^{56}$ Al-Dahabī parece haber adquirido el hábito de resumir obras de Ibn Ḥazm. De hecho, resumió el Kitāa al-muḥallà y le puso el título de Al-Mustaḥlà min Kitāb al-muḥallà. Esto es lo que decía un discípulo (zaăhirí) de al-Dahabī respecto a este resumen: 


\subsection{Sobre la vida de Ibn Hazm}

Después de la fitna beréber, Ibn Hazm se estableció en varias ciudades de al-Andalus. La importancia del manuscrito objeto de este estudio es tal que nos permite conocer los viajes realizados por Ibn Hazm después de la «fitna de Córdoba».

Según el Ṭawq al-ḥamāma, Ibn Ḥazm salió de Córdoba el 1 de muharram de 404/ 1013, dirigiéndose a Almería. Perseguido por Jayrān al- 'Āmirī, se encaminó en seguida hacia el hịsn al-qaṣr (Aznalcázar) y después hacia Valencia tras el advenimiento de al-Murtadà en 407/1016. Posteriormente, en 409/1019 volvió a Córdoba, donde residió hasta la subida al poder del califa omeya 'Abd alRaḥmān V al-Mustaẓhir b. Hišām b. 'Abd al-ŶYabbār b. al-Nāṣir en 414/1023. Unos años más tarde, en 417/1026, se encuentra en Játiva, donde, en opinión de Ị̣sān 'Abbās, fue redactado el Ṭawq al-ḥamāma entre 417-418/1026-1027 ${ }^{57}$.

A partir de la información proporcionada por Ibn Sahl en el manuscrito, se puede trazar un panorama más completo de los desplazamientos de Ibn Hazm. En el único folio que se conserva de la introducción, el autor ofrece una síntesis de la vida de su adversario. Comienza indicando que «Ibn Hazm mantenía divergencias con los alfaquíes de Almería respecto a la qibla y su orientación y, en ciertas ocasiones, hacía la oración junto al cadí de Almería Ibn Sahar ${ }^{58}$. Los alfaquíes se dirigieron al cadí, diciéndole: «una de dos, que rece hacia nuestra qibla o de lo contrario apártalo de ti, porque algún día puede escudarse en ti en contra nuestra». El cadí informó sobre esto a Ibn Ḥazm, el cual dejó Almería y se fue a Denia. Es aquí donde pasó de la doctrina šāfíí a la zāhirí

$$
\begin{aligned}
& \text { رأيت الكتاب الموسوم بالمستحلى من كتاب المحلى الذي اختصره [...] الذهبي [...] وقابلته مع أصله لأرى }
\end{aligned}
$$

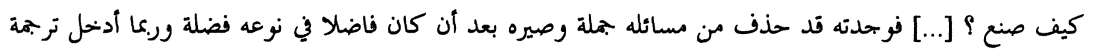

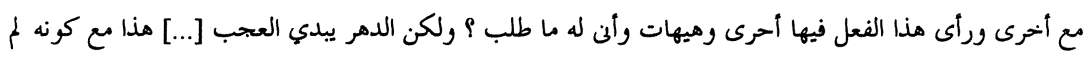

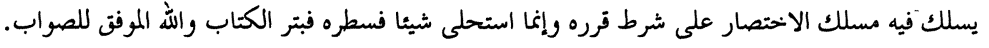

Véase la introducción del autor, en su libro titulado Al-Mawrid al-aḥlà fĩ jtisār al-Muhallà en el manuscrito n. ${ }^{\circ} 40$ qāf de la Biblioteca General de Rabat, microfilm n. 663 , así como M. I. alKattān̄ī, «Hawla kitābayn hāmmayn: Al-Mawrid al-ạ̣là fỉ jtișār al-Muhallà li-bn Hazm wa-l-Qidḥ al-Mu'allà fì ikmāl al-Muhallà li-bn Jalì», Maŷallat Ma'had al-majț̣̂tūt al-arabiyya, 4 (1958), 309-346. Por otro lado, se debe tener presente que al-Dahabĩ catalogó Al-Nukat entre las obras de Ibn Hazm; véase a este respecto Siyar a 'lām al-nubalā', XVIII, 196, nota 2.

${ }^{57}$ Véase la introducción de I. 'Abbās a su edición de Rasā'il Ibn Hazm, I, 38-39.

${ }^{58}$ Se trata de Abū l-Ḥasan Mujtār b. 'Abd al-Raḥmān b. Sahar al-Ru'aynī al-Qurțubī, que se convirtió en cadí de Almería, a petición de sus habitantes y falleció en el año 435/1044. En el texto de Ibn Sahl aparece como un protector de Ibn Hạzm. Para más información sobre su biografía, véase 'Iyād, Tartib al-madārik, VIII, 89. Cabe señalar que Ibn Hazm citó los nombres de seis personas que le brindaron su ayuda en situaciones difíciles. Véase la Risālat al-bayān 'an haqiqqat al-imām en Rasā'il Ibn Hazm, III, 189-190. 
[...], se dedicó intensamente a la escritura y composición de obras y entabló relaciones con el secretario Abū 1-'Abbās b. Rašīiq ${ }^{59}$ al final del reinado de alMuwaffaq Muŷāhid al-'Āmirī ${ }^{60}$. Abū l-'Abbās lo trasladó a Mallorca, teniéndolo en gran estima y tomándolo bajo su protección, pero poniéndole como condición que emitiera fetuas según los principios de la doctrina mālikí, y no según los de la zāhirī. Esto sucedió entre los años 431-440 (del siglo v/XI) ${ }^{61}$. Se le achacaron muchos errores [...]. Los habitantes de Mallorca no podían soportarlo más. También su protector se dio cuenta de su ignorancia y lo equivocado de sus ideas. Él (Ibn Ḥazm) abandonó la isla ${ }^{62}$, dirigiéndose a Denia, después a Sevilla ${ }^{63}$ y posteriormente a una qarya de la región de Niebla, donde falleció en 456/1064 bajo el reinado de al-Mu 'tadid —Dios tenga misericordia de él一, quien había impedido que la gente acudiese a él para estudiar y le prohibió dedicarse a la enseñanza ${ }^{64}$, amenazando con castigar a quien acudiera a él con este fin» ${ }^{65}$. A continuación, añade Ibn Sahl: «Posteriormente, una

${ }^{59}$ Véase su biografía en al-Humaydī, Ŷ̉

${ }^{60}$ Este personaje fue gobernador de Denia y Mallorca durante 36 años a partir del 400/1009. Véase Ibn 'Id̄ārī, Al-Bayān al-mugrib, III, 155-156, y al-Ḥumaydī, Ŷi $\underline{d} w a$, II, 564-566, biografía de Muŷāhid al-'Āmirī.

${ }^{61}$ En un par de ocasiones Ibn al-Abbār determina la fecha en la que llegó Ibn Hazm a Mallorca, situándola después del año 430/1038. Véase Al-Takmila, II, 301, y IV, 154-155.

62 Curiosamente, Ibn Sahl silencia la conocida confrontación polémica entre al-Bāŷī e Ibn Hazm. No obstante, en una parte muy deteriorada del manuscrito del Tanbih he podido observar la expresión qāla Abū l-Walìd, como si Ibn Sahl reprodujese el párrafo de un debate entre Abū 1-Walīd al-Bāŷī e Ibn Ḥazm en relación con al-Qur'ān kalām Allāh gayr majlūq. Esta hipótesis aparece reforzada por el hecho de que Ibn Hazm mencionase que «al-Bāŷī es un jefe supremo de los aš'aríes de nuestros días». Véase Al-Fișal, I, 161, y V, 77. Respecto a las discusiones sobre uṣül al-fiqh entre Ibn Hazm y al-Bāŷī, cfr. Abdel Magid Turki, Polémiques entre Ibn Hazm et Bāğī sur les principes de la loi musulmane. Essai sur le littéralisme zahirite et la finalité malikite, Argel, 1973.

${ }^{63}$ Como ya he mencionado, antes de ir a Sevilla, Ibn Hazm regresó a Almería en el período comprendido entre los años 441-445/1049-1053.

${ }^{64}$ Este relato coincide con el ofrecido por Ibn Hayyān. Véase Ibn Bassām, Al-Dajīra, I, 168-169. Se trata, sin duda, de «la vigilancia a la que fue sometido este sabio zāhirí durante los últimos años de su vida».

وكان ربما صلى إلى جنب القاضي ابن سهر كذلك فتلق فقهاء المرية من ذلك وحاؤوا إلى القاضي وقالوا 65

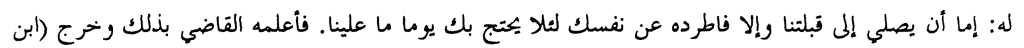

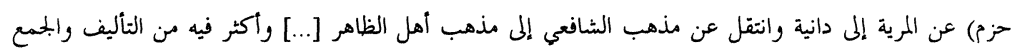

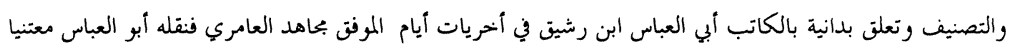

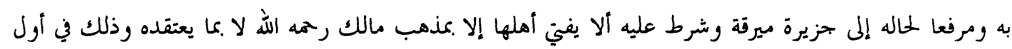

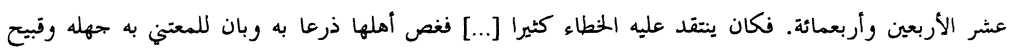

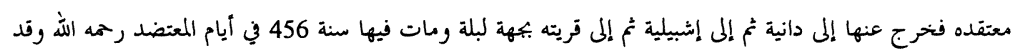

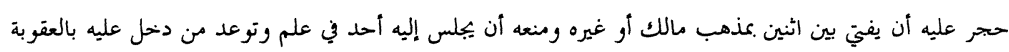

$$
\text { والأدب. }
$$


minoría que carece de fe, de razón y de oportunidad en el paraíso (lā jalāq la$h \bar{a}$ ) ha sido deslumbrada por su doctrina, prefería la lectura de sus obras [...]; por esta razón, he decidido subrayar «el error» (qubḥ) de su doctrina [...] y citar una muestra de su ignorancia tomada de sus escritos, así como de su extremismo, en el que no incurrieron los autores precedentes ni los posteriores» ${ }^{66}$.

\section{LA PROPAGANDA CONTRA IBN HAZM}

El hecho de que Ibn Sahl se afanase en criticar a Ibn Hazm refleja hasta qué extremo llegaba el odio que le profesaba. En este sentido, declara: «me han informado de que no aprendió el Corán de memoria, ya que se limitó a breves capítulos» (wa-qad ujbirtu anna-hu kāna lā yahfaẓu min-hu (al-Qur'ān) illā l-mufaṣșal). Asimismo, dice: «pero sabe los Salmos de memoria y eso es como su preocupación por la lógica, que — según él—es, en realidad, el único medio para el conocimiento de la verdad» (wa-anna-hu kāna yahfaẓu al-zabūr wa-huwa kaištigāli-hi bi-šarḥ hạadd al-manțiq wa-qawli-hi anna-hu lā tatimmu ma'rifat al-ašy $\bar{a}$ ' haqiqa illā bi-hi). En otra parte, Ibn Sahl acusa a Ibn Hazm de recurrir a una serie de artimañas con el fin de difundir su doctrina en Mallorca ${ }^{67}$.

Por otro lado, es preciso plantearse quién es la persona que proporcionó a Ibn Sahl este tipo de información. El autor declara que «me informó alguien que lo ha observado muy de cerca» (wa-qad ajbara-nì man iț̣ala'a 'alà amri-hi).

Antes de continuar, quiero llamar la atención del lector sobre una carta anónima dirigida a Ibn Hazm. Varios pasajes de esta misiva se conservan en la réplica redactada por este último a este respecto, titulada Risāla fi $l$-radd 'alà al-hātif $\min b u$ 'd. Al final de ésta se halla un texto importante, en el cual Ibn Hazm indica de forma explícita los nombres de dos personas que vertieron calumnias contra él: Ibn al-Bāriya y al-'Utaqī. He aquí lo que dijo sobre ambos: «Hemos pedido al maldito apóstata Ibn al-Bāriya que se arrepienta ante Dios de las mentiras y calumnias que ha lanzado contra nosotros en vuestra presen-

$$
\begin{aligned}
& \text { ومالت شرذمة لا دين عندها ولا عقل معها ولا خلاق لها إلى القول بمذهبه ومطالعة تواليفه [...] فرأيت } 66 \text { فر }
\end{aligned}
$$

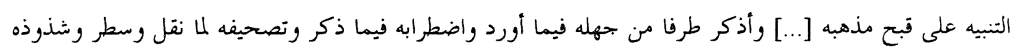

$$
\begin{aligned}
& \text {. مكا لم يقله أحد ممن تقدم أو تأخر. }
\end{aligned}
$$

${ }^{67}$ Véase al respecto el texto árabe completo en el anexo n. ${ }^{\circ} 5$ de este artículo. 


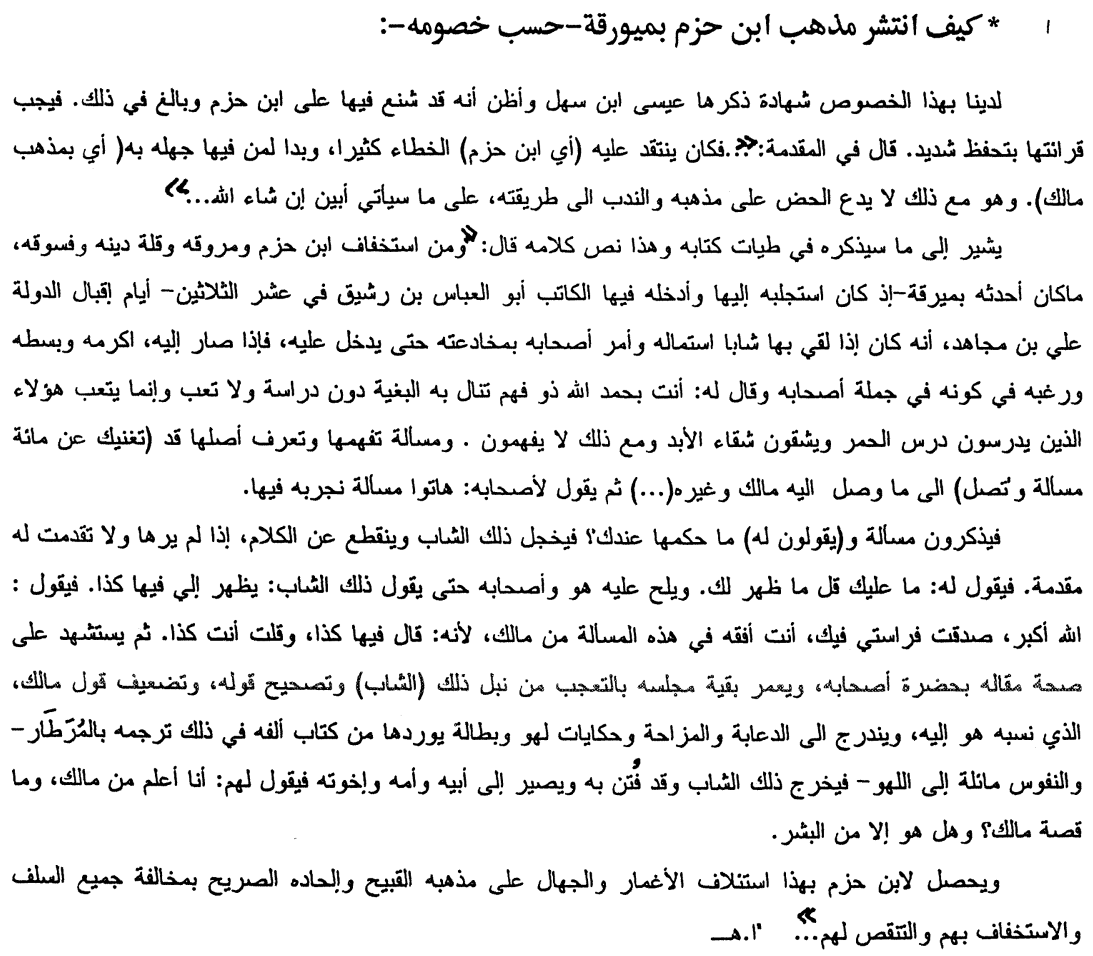

Anexo n. ${ }^{\circ} 5$.

cia: asimismo, hemos encontrado a al-'Utaqī, ése que ha engañado a algunos de vosotros» 68 .

Mientras que al-'Utaqī continúa siendo un desconocido hasta nuestros días, no es éste el caso de Ibn al-Bāriya, que ha sido citado por Ibn al-Abbār ${ }^{69}$ y por el cadí 'Iyāọ ${ }^{70}$. Las versiones de sus dos principales biógrafos se complementan entre sí. Ofrezco a continuación la versión de Ibn al-Abbār, completándola con la de 'Iyāọ: «Abū l-Walīd b. al-Bāriya, de la gente de Mallorca, era uno de los alfaquíes mālikíes más eminentes de su generación [...]. A raíz de la llegada de Abū Muhammad b. Hazm a Mallorca - después del año

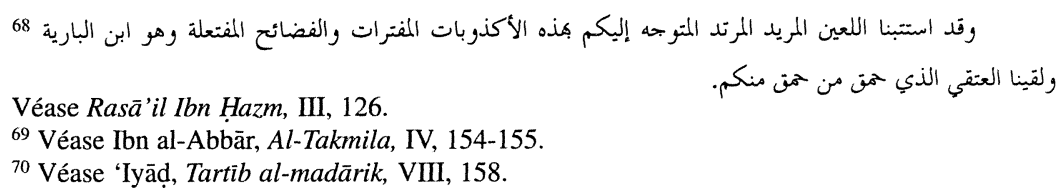


430/1038 - y la difusión de su doctrina en la isla, se desarrolló un debate entre este último y Abū l-Walīd [en relación con la adopción del rito mālikí], en el curso del cual este último incurrió en un error. Ibn Hazm [que se ha comportado como un fanático] exageró su crítica [hasta el punto de inducir al gobernador a humillar y encarcelar a su adversario] en presencia de Abū l'Abbās Aḥmad b. Rašīq [...]. Ibn al-Bāriya fue obligado a arrepentirse, permaneció varios días en prisión y posteriormente fue puesto en libertad. Inmediatamente después abandonó la isla, dirigiéndose a La Meca, donde falleció» ${ }^{71}$. [El cadí Abū 1-Walīd al-Bāŷì había mencionado esto en su obra Al-Firaq $]^{72}$.

Sin embargo, la parte final de la versión de Ibn al-Abbār, según la cual, «tras abandonar Ibn al-Bāriya Mallorca, se dirigió a La Meca» es discutible, porque no coincide con lo que había dicho Ibn Hazm. Así pues, no se deben tomar al pie de la letra las palabras de Ibn al-Abbār, sino más bien suponer que Ibn al-Bāriya intentó vengarse de su adversario, vertiendo mentiras y calumnias contra él.

Es preciso plantearse si Ibn al-Bāriya llegó a mantener algún contacto con 'İsà b. Sahl. En mi opinión, existen algunos aspectos que me llevan a plantear esta posibilidad. Por ejemplo, la carta anónima, que he mencionado, presenta el mismo estilo de Ibn Sahl. Además, leyendo el manuscrito del Tanbìh, he podido constatar, por primera vez, esta similitud sorprendente, no sólo en cuanto al estilo se refiere, sino también en relación con las críticas y los argumentos. Por esta razón, no me cabe la menor duda de que Ibn Sahl es el autor anónimo al que se refirió Ibn Hazm como al-hātif min bu'd.

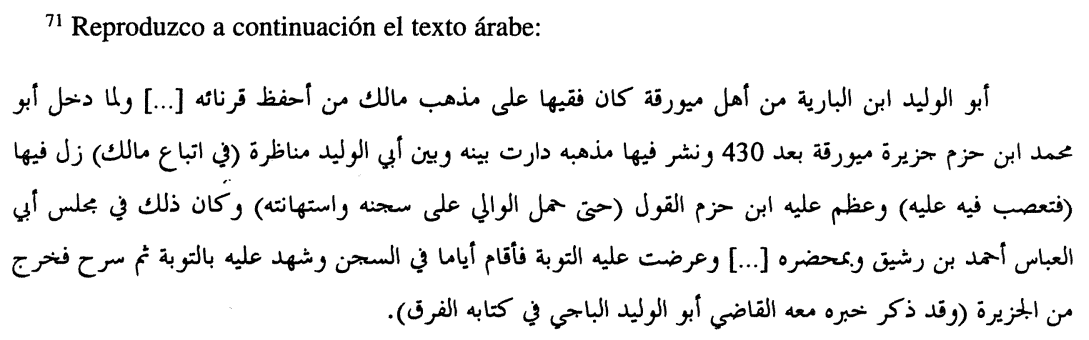

\footnotetext{
${ }^{72}$ Texto mencionado por 'Iyād como Kitāb firaq al-fuqahā' en op. cit., VIII, 125. Algunos pasajes de esta obra han sido citados por Abū 'Abd Allāh Muhammad b. 'Alī b. al-Azraq al-Himyarī al-Garnātī (m. 896/1491) en su obra titulada Rawdat al-i' lām bi-manzilat al- 'arabiyya min 'ulīm al-isläm, ed. S. al-'Alamī, Libia, 1999, II, 550-554 y 567-570. Mientras que el primer pasaje reproduce un debate entre al-Bāŷĩ y un ší í imamí en Alepo en el año 437/1046, el segundo aborda una discusión sostenida en Murcia entre al-Bāŷî̀ y al-Hawzanī.
} 
A modo ilustrativo, a continuación ofrezco la confrontación de algunos párrafos del Tanbih , por una parte, y de la carta anónima extraída de la réplica de Ibn Hazm, por otra:

\begin{tabular}{|c|c|}
\hline 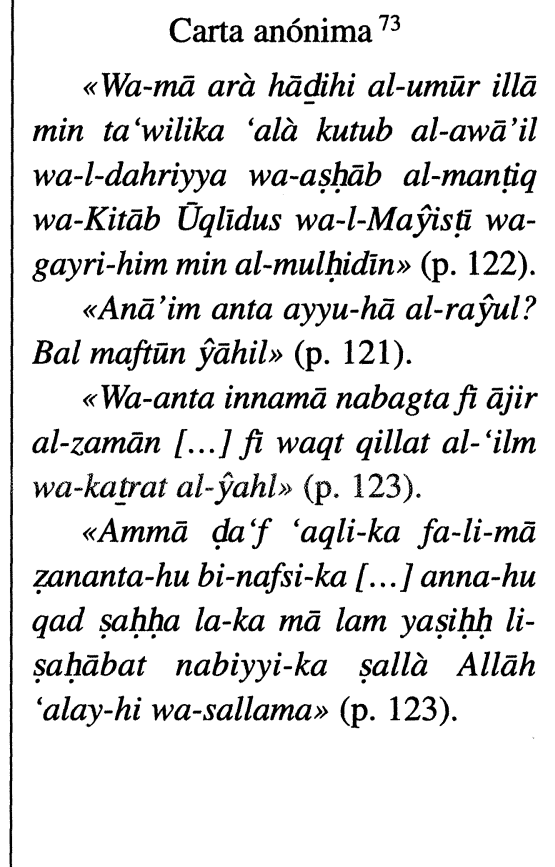 & 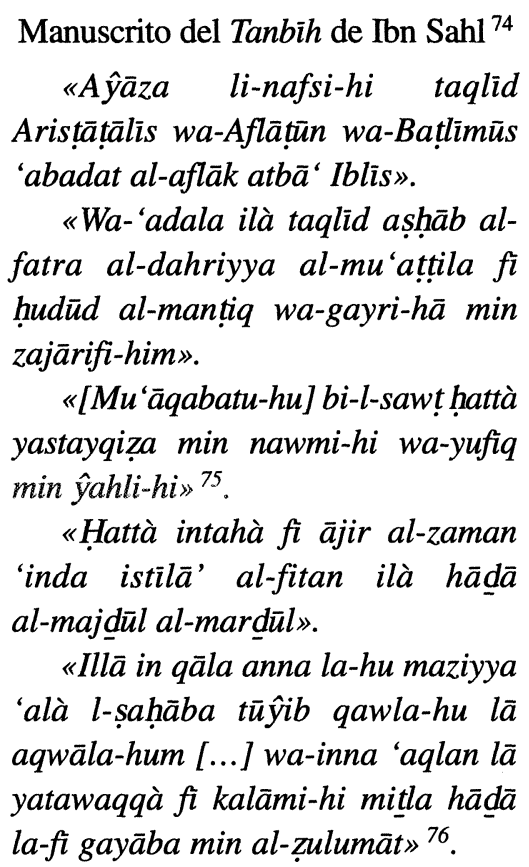 \\
\hline
\end{tabular}

El texto relativo a las severas medidas impuestas a Ibn Hazm por al$\mathrm{Mu}$ 'taḍid, mencionado anteriormente, refleja cierto alivio y satisfacción por parte de Ibn Sahl, quien invoca la misericordia de Dios sobre al-Mu'tadid (después de su muerte), mientras que no actúa del mismo modo con su maestro Ibn 'Abd al-Barr, amigo de Ibn Hazm. La carta anónima demuestra que la persecución de que fue objeto Ibn Ḥazm respondió a un complot de Ibn Sahl y sus pares.

Al final de la carta, el autor (Ibn Sahl) dirige una advertencia a Ibn Ḥazm en un tono amenazante: «Si tú no te despiertas de tu sueño y no te das cuenta

\footnotetext{
${ }^{73}$ Pasajes extraídos de «Al-Radd 'alà 1-hātif min bu'd» de las Rasā'il Ibn Hazm, III, 119-128.

${ }^{74}$ Microfilm n. 5 de la Biblioteca General de Rabat.

${ }^{75} \mathrm{Ibidem}$, «Faṣl fị dikr mā šadda fî-hi 'an al-umma» (mas 'ala 4, 2).

${ }^{76}$ Ibidem (mas 'ala 3, 7). Se podrían dar ejemplos de otros pasajes de la carta anónima y del manuscrito del Tanbìh.
} 
de tu necedad - arrepintiéndote de tus pecados_ llegarán a ti y a quien se dirige a ti o te protege las respuestas de los sabios de todo el orbe, que conocerás más adelante» ${ }^{77}$.

Pero el acto más abominable fue la incineración de las obras de Ibn Hazm, hecho que tuvo lugar en Sevilla bajo el reinado de al-Mu'tadid en vida de Ibn Hazm, quien recitó unos versos a este respecto ${ }^{78}$.

Ibn Hazm, en su réplica a la carta anónima respondió con orgullo a la amenaza precedente, diciendo: «Dios Altísimo te depare a ti y a tus iguales - con respecto a lo que me ayudó a componer - una prolongada tristeza y una gran vergüenza, así como una refutación hacia todo $r a^{\prime} y$ y qiyās, y un gran triunfo en favor de la sunna» ${ }^{79}$.

\section{LA OPINIÓN DE IBN SAHL SOBRE EL PROBLEMA DE LA CORRUPCIÓN DE LAS ESCRITURAS}

En el manuscrito objeto de este artículo, Ibn Sahl critica a Ibn Hazm debido a sus aserciones sobre «la corrupción de la Biblia», expuestas en su Risālat al-tawqîf 'alà šāri' al-nầāt bi-jtișār al-țarīq al-mu'addiya ilay-hi ${ }^{80}$.

A continuación, expongo la crítica de Ibn Sahl: «él ha seguido el mismo procedimiento contra los magos [...] y se ha equivocado de camino [...], cuando debería haberse limitado a decir que cualquier otra religión fue abrogada por la llegada del sello de los Profetas en razón de la revelación que se había recibido bajo la forma de Libro Perfecto. Dios había dicho que «quien elija una religión distinta al Islam, ésta no será aceptada y en el Último Día él se contará entre los

77 al-Radd 'alà l-hātif min bu'd, especialmente 125-126.

${ }^{78} \mathrm{Al}$ principio Ibn Hazm mantenía una buena relación con al-Mu 'tadid, como prueba el hecho de que le dedicase el Fișal. En la introducción del manuscrito de esta obra preservado en al-Azhar y en el British Museum se puede leer el siguiente párrafo, que no ha sido impreso:

$$
\begin{aligned}
& \text { وأن الأمير المعتضد باللة أبا عمرر عباد بن محمد بن إسماعيل بن عباد اللخمي الماجد الشريف الحسيب أدام }
\end{aligned}
$$

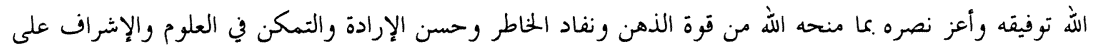

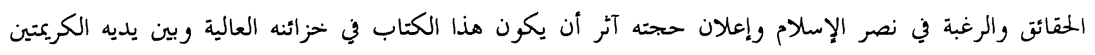

$$
\begin{aligned}
& \text { فسارعت إلى غرضه. }
\end{aligned}
$$

M. A. Himāya, Ibn Hazm wa-man haŷu-hu f-dirāsat al-adyān, El Cairo, 1983, 112.

${ }^{79}$ Referencia citada anteriormente; véase p. 127.

${ }^{80}$ Véase Rasā'il Ibn Hazm, III, 131-140, especialmente 137-139. Para una visión general de la opinión de Ibn Ḥazm sobre la Biblia hebrea, véase C. Adang, Islam frente a judaísmo: la polémica de Ibn Hazm de Córdoba, Madrid, 1994. 
perdedores» ${ }^{81}[\ldots]$. Los judíos y los cristianos dijeron entonces a Ibn Hazm: «Nosotros seguimos (la senda) de las religiones que nos han transmitido nuestros profetas y si tú niegas eso, serás un infiel y deberás ser ejecutado según tu ley, puesto que no crees en el mensaje que vuestro Profeta os ha transmitido en el Corán, es decir, que Dios nos envió mensajeros a los que reveló la Torah y el Evangelio [...]. Y la corrupción cometida por algunos de nosotros no prueba la invalidez de nuestra religión, del mismo modo que en nuestro caso vuestra religión no ha sido invalidada por la aparición de los jāriŷ́es y de algunas sectas extraviadas». A continuación, dice Ibn Sahl: «Este argumento es irrefutable y demuestra categóricamente las calumnias proferidas por Ibn Hazm» ${ }^{82}$.

Esta opinión de Ibn Sahl parece haber gozado de cierta difusión en al-Andalus en el siglo v/XI, puesto que el mismo Ibn Hazm la había refutado anteriormente en su obra Al-Fiṣal (en dos páginas y media) ${ }^{83}$.

\section{CONCLUSIÓN}

Como ya he mencionado anteriormente, Ibn Sahl y sus pares provocaron la persecución de Ibn Hazm, si bien esta represión nunca llegó a prosperar. Prueba de ello es este manuscrito de Ibn Sahl, quien, más de veinte años después del fallecimiento de Ibn Hazm, se sintió en la necesidad de refutar in extenso las ideas de Ibn Hazm, que cada vez más atraían la atención de lectores y discípulos ${ }^{84}$.

${ }^{81}$ El Corán, III, 84.

وسلك مثل هذه السبيل فيما ذكر عن البحوس [...] فحاد عن الطريق [...] وكان يكفيه أن يقول: إن الملل

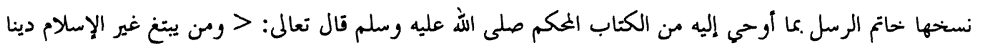

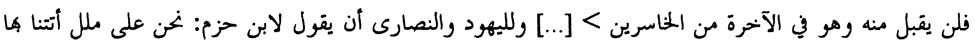

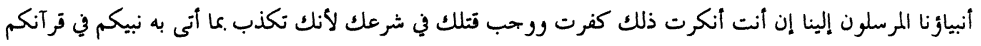

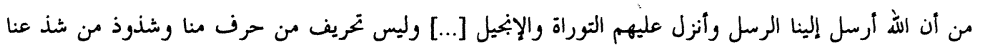

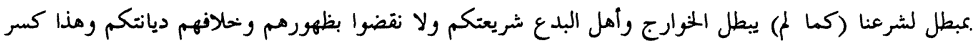

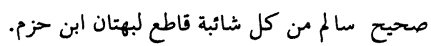

${ }^{83}$ Véase Ibn Hazm, Al-Fisal fi l-milal wa-l-ahwä' wa-l-nihal, ed. al-Ŷamālī, El Cairo 1902, I, 215-217; Beirut, 1985, I, 317-320. Sin embargo, Ibn Sahl vocalizó el título de su obra así: Kitāb al-faṣl fi l-milal wa-l-nị̣al, lo cual apoya la opinión que M. 'Alī Ḥimãya ha formulado a este respecto. Véase la referencia citada en la nota 78.

${ }^{84}$ Sobre los discípulos de Ibn Hazm, véanse los artículos de C. Adang, «Zāhirīs of Almohad Times» Estudios onomástico-biográficos de al-Andalus. X. Biografías almohades. II, ed. M. L. Ávila y M. Fierro, Madrid-Granada, 2000, 413-479, y «The Spread of Zāhirism in the Țā' ifa and Almoravid Periods», en prensa. 
La historia ha inmortalizado a este zāhirí, sin precedente ni sucesor, a quien el alfaquí Ibn al-'Arabī calificó de «un ignorante de la región de Niebla» ${ }^{85}$.

En este artículo no he abordado el lugar que ocupa el Tanbīh de Ibn Sahl en la literatura marroquí y andalusí anti-hiazmí, cuestión que espero tratar en un futuro estudio especialmente reservado a este tipo de literatura.

\section{RESUMEN}

En este artículo se aborda el estudio de un fragmento manuscrito andalusí que contiene una crítica dirigida a la doctrina zāhirí de Ibn Hazm. En primer lugar, se intenta determinar el título de la obra y la identidad del autor. Posteriormente, se ofrece una estimación aproximada de la fecha y el lugar de composición del libro. Por último, se proporciona información relevante en torno a la figura de Ibn Ḥazm, sus obras, sus adversarios, sus protectores, al igual que sobre el autor del fragmento.

El valor histórico del manuscrito es realmente considerable, por lo que aprovecho estas líneas para expresar mi deseo de que en el futuro otros investigadores puedan localizar otro ejemplar de este fragmento que, de algún modo, permita completar la información proporcionada por el deteriorado manuscrito, actualmente preservado en la Biblioteca de al-Qarawiyyīn de Fez, y cuyo microfilm se halla en la Biblioteca General de Rabat.

\section{ABSTRACT}

This article presents an unpublished fragment of an Andalusí manuscript of a text criticizing Ibn Hazm. Identifications are offered of the title of the work and its author, as well as suggestions as to where it was composed. The text also provides valuable information about Ibn Hazm, his writings, his opponents and those who protected him as well as about the author of the text itself.

The historical value of the manuscript is great, but the manuscript is incomplete. It is to be hoped that this article will make it possible to discover another manuscript whose contents complement and perhaps complete those of this manuscript, in poor condition, preserved in Fez and, in microfilm, in the Bibliothèque Genèrale de Rabat.

${ }^{85}$ Véase Abū Bakr b. al-'Arabī, Al- 'Awāṣsim min al-qawāṣim, ed. 'A. al-Ṭālibī, Argel, 1974, II, 136 y 336. Al-Ḍahabī se rebela contra esta injuria en su obra, diciendo:

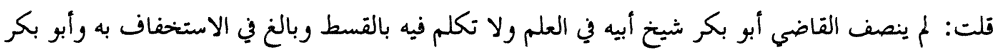

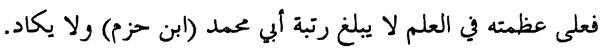

